\title{
Cell-Mediated Immunity Multitest
}

National Cancer Institute

\section{Source}

National Cancer Institute. Cell-Mediated Immunity Multitest. NCI Thesaurus. Code C17996.

Multitest CMI is a diagnostic technique for detection of anergy (nonresponsiveness to antigens) by means of delayed hypersensitivity skin testing. This test uses seven antigens: tuberculin, tetanus, diphtheria, Streptococcus, Candida, Trichophyton, and Proteus to test for cutaneous delayed-type hypersensitivity responses in humans. The test is administered by pressing the antigen heads of the Multitest applicator firmly onto the volar surface of the lower arm. A positive reaction to an antigen is manifest as an inflammatory response at the site of administration. 